\title{
ЗАТЛЪСТЯВАНЕ В ДЕТСКА ВЪЗРАСТ
}

\author{
Димитричка Близнакова ${ }^{1}$, Светла Стайкова ${ }^{3}$, Валентина Маджова² \\ ${ }^{1}$ Медицински колеж, Медицински университет - Варна \\ ${ }^{2}$ Катедра по обща медицина и клинична лаборатория, \\ Медицински университет - Варна \\ ${ }^{3}$ Втора катедра по вътрешни болести, Медицински университет - Варна
}

Затлъстяването при деца е сериозен проблем с много здравни и социални последствия, които продължават и в зряла възраст. Епидемичното увеличаване на затлъстяването през последните десетилетия засяга децата и юношите в развитите страни в цял свят и го превръща в едно от най-честите педиатрични заболявания. Оценяването му в детска възраст е важно поради това, че то може да има значителни физически и емоционални последствия за децата, за тяхната себеоценка и качество на живот. За предотвратяване на затлъстяването при децата е особено важно да се стимулира физическата активност и здравословното хранене в ранна възраст. Водеща роля за това имат родители и учители.

Персистирането на затлъстяването от детска в зряла възраст зависи от фактори като начална възраст, тежест на заболяването, наличие на затлъстяване при поне един от родителите. Рискът дете с наднормено тегло да остане със затлъстяване като възрастен се увеличава правопропорционално на възрастта над 3 години, като за възраст над 6 години е 50\%, а за юношеска - над 70-80\%. Тежестта на състоянието и наличието на фамилна обремененост увеличава риска за всяка възраст, при един родител с 50\%, при двама - с 80\%. Механизмите, които довеждат до затлъстяване, са: повишен внос на храна, намален енергиен разход, първично нарушение в мастната обмяна с повишена синтеза и разграждане на масти, нарушена регулация на апетита.

\section{Какво определя значимостта на проблема затлъстяване?}

- Увеличаване честотата му сред деца, подрастващи, възрастни;

- Усложненията, до които води със засягане на сърдечно-съдовата, централната нервна система;
- Развитие на диабет тип 2;

- Засягане на отделителната система с увеличаване честота на ХБЗ.

Затлъстяването е най-разпространеното хронично метаболитно заболяване на нашето съвремие с много сериозни последици. Според СЗО то е глобална епидемия и значителен проблем на общественото здраве. В развитите страни наднорменото тегло и затлъстяването придобиват мащабни размери, особено в развитите страни. В края на 2010 год. според СЗО около 43 милиона деца под 5-год. възраст са с наднормено тегло. В Европа те са над 22 милиона и около 5 милиона страдат от затльстяване. България е сред първите 6 страни в Европа. Данни от САЩ сочат за нарастване и утрояване на броя на затлъстелите деца през последните години, като за 2015-2016 година близо 1 на всеки 5 деца и млади хора в училищна възраст имат затлъстяване. Най-висок е относителният дял на децата с наднормено тегло и затлъстяване в началото на пубертета: 10-год. възраст при момичета и 13-год. възраст при момчета.

- Детското затлъстяване е едно от най-сериозните предизвикателства на 21 век. Международната работна група по затльстяване е обърнала внимание на детското затлъстяване като глобална „криза на детското здраве“.

- Детското затлъстяване има непосредствено и дългосрочно въздействие върху физическото, социалното и емоционалното здраве.

- Децата със затлъстяване са изложени на по-висок риск от други хронични заболявания и такива, които оказват влияние върху физическото здраве. Те включват астма, сънна апнея, проблеми с костите и ставите, диабет тип 2 и рискови фактори за сърдечно-съдови заболявания. 
- Децата със затлъстяване са тормозени и дразнени повече от връстниците си и са склонни да страдат от социална изолация, депресия и ниско самочувствие.

Изключително е тревожно и това, че децата стават затлъстели възрастни със същите съпътстващи усложнения: диабет, сърдечно-съдови, мозъчно-съдови и др. Старата двойка Затлъстяване-Диабет е позната още от древността. В по-ново време затлъстяването е наричано „будилник на диабета“, а французинът Гине изказва афоризма, че „болният започва като затлъстял, след това става диабетик, за да завърши накрая със сърдечно-съдово отклонение".

Познаването на проблема Затлъстяване изисква да се познават причините, които са довели до това. Те могат да се групират в две основни групи: променливи и непроменливи.

\section{Непроменливи причини за затлъстяване:}

- Генетични фактори

През последните години се появиха много проучвания за ролята на генетичните фактори, водещи до затлъстяване. Последното е комплексно, полигенно метаболитно състояние, рядко резултат на единични гени. Известни са над 420 гени, асоциирани с него. Не трябва да се приема наследствеността като фаталност и съзнателно да се регулират както хранителните навици, така и качеството на живот.

- Променливи причини за затлъстяване

Вредни хранителни навици. Обсъждайки детската възраст не можем да пропуснем храненето в кърмаческия период. Преминаването на смесено и изкуствено хранене, ранното захранване са фактори, които могат да доведат до затлъстяване още от тази възраст. В ранното детство храненето с високо енергийни храни, злоупотребата със сладки храни, напитки, тестени изделия са предразполагащ фактор за затлъстяване.

\section{Намалена двигателна активност.}

\section{Стрес.}

Допълнителни рискови фактори в детска възраст могат да бъдат: оперативна интервенция, най-често тонзилектомия, остро заболяване с прехранване в реконвалесцентния период, хронично заболяване с продължително обездвижване, продължително лечение с кортикостероиди.
Ендокринни причини за затлъстяване: Могат да бъдат хипотиреоидизъм, хиперкортицизъм, хиперинсулинизъм, псевдохипопаратиреоидизъм, вродени малформации, които водят до затлъстяване.

Болестни процеси в областта на ЦНС: Апетитът се контролира от хипоталамични ядра, отговарящи за чувство на глад и ситост.

Затлъстяването е хронично състояние, което се характеризира с натрупване на мастна тъкан в организма, дължащо се на увеличение на размерите и/или броя на мастните клетки. Храната е основен източник на енергия и пластичен материал. Правилното функциониране на организма се определя от баланса между енергийния внос и енергийния разход. В регулацията на апетита ключово място заемат инсулинът и кръвната глюкоза. Мастната тъкан с нейните хормони въздейства върху центровете на апетита и ситостта. Дразненето на зрителния, слуховия, обонятелния нерв са допълнителен стимул за повишаване на апетита. Емоционалното хранене, здраво-словното състояние, възпитанието въздействат също върху хипоталамуса. Апетитът и неговата регулация са изключително сложен процес, кодиран от гените, предаващ се от поколение на поколение.

Синдромно затлъстяване. То се характеризира със специфичен фенотип: малформативни стигми при някои синдроми с доказани генни дефекти, умствено изоставане, изоставане в растежа, често асоциирани аномалии на костите, бъбреците, сърдечно-съдови и очни, специфични психосоциални проблеми, налагащи екипен подход при лечението им. Известни синдроми със затлъстяване ca: Prader-LabhartWill syndrome, Laurence-Moon-Bardet-Biedle syndrome. Затлъстяване може да се наблюдава и при Down syndrome, Turner syndrome. Интерес представляват и синдромите, свързани с лептиновия хормон: вроден лептинов дефицит и мутация на гена за лептиновия рецептор. При някои хора със затлъстяване са установени повишени нива на лептин, което дава основание да се обсъжда лептинова резистентност. Прогнозата на синдромното затлъстяване е сериозна, особено в случаите със засягане на бъбреците и сърцето.

Просто затлъстяване. Най-често срещан и е един от основните признаци на метабо- 
литния синдром, който стартира още в детска възраст.

Водещи симптоми за поставяне диагноза затлъстяване са увеличението на подкожната мастна тъкан и нейното разпределение. Детето се измерва на ръст и тегло, като стойностите се сравняват със стандартните криви на съответната възраст. Изчислява се индексът на телесна маса (ИТМ = теглото в кг/ръста м $^{2}-$ Body mass index - ВMI), който се сравнява със съответните стандарти и растежни криви и таблици. Определя се т.нар. персентил на детското тегло. Ако то е в 80 персентил, това означава, че $80 \%$ от децата на тази възраст са с тегло пониско от неговото. Счита се, че:

- BMI за съответните пол и възраст в диапазона 5-50 персентил теглото е в норма.

- BMI над 90 персентил за съответните пол и възраст е признак за наднормено тегло;

- BMI над 95 персентил за съответните пол и възраст е признак за затлъстяване.

Има няколко класификации за определяне степента на затлъстяването. Най-широко се използват критериите на С3О, основани на ИТМ ( $\mathrm{BMI})$ :

- I степен BMI: 25-29,9kg/m² (наднормено тегло);

- IIстепенBMI:30-39,9 kg/m² (затлъстяване);

- III BMI: 40 kg/m² (или повече), (тежко или болестно затлъстяване).

При прегледа на детето може да установим:

- Acantosis nigricans: признак за инсулинова резистентност, който корелира с тежестта й.

- Съотношение талия/ханш.

- Наличие на активни стрии. Често се среща при простото затлъстяване във връзка с т.нар. „функционален хиперкортицизъм“. Съчетанието му с артериална хипертония изисква изключване на първичен или вторичен хиперкортизолизъм.

- Артериално налягане и пулсова честота.

- Изменения в костно-ставния апарат.

- Промени в чернодробната функция стеатоза на черния дроб.

Усложненията на затлъстяването при деца обхващат почти всички органи и системи: сърдечно-съдова, дихателна, храносмилателна, ендокринна, отделителна, опорно-двигателна, кръвотворна.
От важно значение е засягането на отделителната система при затлъстяване. Затлъстелите деца имат по-големи бъбреци и повишен бъбречен кръвоток, отколкото тези с нормална телесна маса.

Установеното наднормено тегло е риск за хронично бъбречно увреждане. Затлъстяването и раждането преди 36 г.с. са сред най-рисковите фактори за появата на бъбречно заболяване у децата.

Затлъстяването води до увреждане на бъбреците чрез директни механизми от различни цитокини от мастната тъкан с нефротоксичен ефект. Той може да предизвика бъбречна дисфункция и увреждане на бъбреците дори без диабет и хипертония. През последните години се обръща особено внимание на въздействието на затлъстяването не само върху хипертонията, коронарните съдови заболявания и инсулиновата резистентност, но и върху бъбреците. Затлъстелите деца, дори при отсъствие на диабет, могат да имат гломеруломегалия, промени в гломерулната базална мембрана, пролиферация на мезангиума, фокална сегментна гломерулна склероза и албуминурия. Увеличава се броят на пациентите с наднормено тегло, затлъстяване и ХБЗ. Проучвания на калифорнийски автори показва връзката между изходния ВMІ и риска от ХБЗ при деца. В друго проучване - при трансплантирани пациенти, получили бъбреци от затлъстели донори, се установява намаление на СГФ и по-висока степен на алографтна дисфункция, отколкото бъбреците, получени от слаби индивиди. Все повече епидемиологични изследвания и клинични наблюдения предполагат, че метаболитният синдром при затлъстяване играе ключова роля в развитието на ХБЗ.

Разпространението на ХБЗ е приблизително два пъти повече през последните три десетилетия, успоредно с нарастващия брой на случаите със затлъстяване и инсулинова резистентност, която се наблюдава и при детското население в цял свят. В момента около 1/5 от децата и юношите в индустриализираните страни са с наднормено тегло или затлъстяване. Така то е реална заплаха не само за здравето на децата и юношите, но също така и за възрастните, тъй като метаболитните, сърдечно-съдовите въздействия на затлъстяването се коренят в детството. Затлъстяването е не 
само коморбидност за ХБЗ, но може да бъде и рисков фактор за бъбречна недостатъчност. Ниското тегло при раждане и малката нефронна маса водят до хронифициране на бъбречните заболявания. Повишени нива на адипокини, като лептин и адипонектин, могат да бъдат важен фактор в патогенезата на ХБЗ. Други фактори, като $A X$, увеличаване на сърдечно-съдовата заболяемост, инсулинова резистентност, дислипидемия, могат да играят значителна роля в патогенезата на затлъстяването $и$ ХБЗ.

При пациенти със затлъстяване, при които липсват белези за бъбречно заболяване, при биопсия се откриват патологични промени в гломерулите, като честотата им корелира с индекса на телесна маса. Затлъстяването е свързано с гломерулна хиперфилтрация и хипертония. Така наречената „свързана със затлъстяване гломерулопатия" клинично се характеризира с висок серумен албумин, умерена протеинурия (микроалбуминурия се наблюдава в $10 \%$ от затлъстелите деца), минимален оток, понижен серумен холестерол. Гломерулопатията, свързана със затлъстяване, е описана като вторична форма на фокална сегментна гломерулосклероза. Морфологично тя се определя като гломеруломегалия със или без фокална сегментна гломерулосклероза, поради функционалните и структурни промени в бъбрека. Инсулинът е свързан с настъпването на гломерулна хиперперфузия и хиперфилтрация, водеща до мезангиална бъбречна клетъчна пролиферация, увеличаване на протеинурията, увеличена активност на системата ренин-ангиотензин-алдостерон, което води до АХ. Освен това инсулинът стимулира производството на провъзпалителни цитокини от мастната тъкан, които са свързани с нарушено производство на азотен оксид и промяна на статуса окислител/антиоксидант. Хипергликемията е пряко свързана с бъбречната хиперфилтрация и хиперперфузия и причинно свързана със съдова и гломерулна дисфункция.

Плазмените концентрации на някои възпалителни медиатори като TNF- $\alpha$, CRP, IL-6 ca повишени при пациенти с метаболитен синдром. Последните данни показват, че възпалението е свързано със затлъстяване при деца с ХБЗ. Наднорменото тегло и затлъстяването са свързани с много рискови фактори като хи- перинсулинизъм, хипертония, нарушен глюкозен метаболизъм, хиперлипидемия, активност на ренин-ангеотензин-алдостерон, оксидативен стрес и провъзпалителни цитокини.

Доказано е, че по-високият показател на BMI е свързан с повишена честота на нефролитиазата. Затлъстяването е свързано с редица рискови фактори, допринасящи за по-високата честота и разпространение на нефролитиазата. По-високото телесно тегло е свързано с по-ниски стойности на $\mathrm{pH}$ на урината, увеличени оксалати в урината, екскреция на пикочна киселина, натрий и фосфати. Диетите, които са по-богати на протеини и натрий, могат да доведат до по-кисела урина, намаляване на уринния цитрат и риск от образуване на камъни. Инсулиновата резистентност, характерна за затлъстяването, също може да предразположи към нефролитиаза чрез въздействие върху тубулите и поддържане на кисела среда.

Механизмите за повишен риск от рак на бъбреците при затлъстели не са толкова добре проучени. Инсулиновата резистентност и последващата хронична хиперинсулинемия, повишеното производство на инсулиноподобен растежен фактор 1 и многобройните комплексни вторични хуморални ефекти могат да окажат стимулиращо действие върху растежа на различни типове туморни клетки. Напоследък се появяват и допълнителни обяснения за ендокринните функции на мастната тъкан, ефектите й върху имунитета и генерирането на възпалителна среда със сложни ефекти върху раковите заболявания.

Затлъстяването е изключително сериозно и тежко хронично заболяване. Значението му се определя от високата честота в детска възраст и усложненията, до които довежда. То е в основата на метаболитния синдром, който стартира още в детска възраст.

Световната епидемия от затлъстяване засяга населението на Земята по много начини. Болестите на бъбреците - ХБЗ, нефролитиазата и ракът, са сред най-коварните последици на затлъстяването.

Желателно е провеждане на психообразувателни и поведенчески програми на ниво:

- Индивидуално с мотивационни интервюта;

- Семейство с оглед познания, поведенчески, хранителни, двигателни навици, ак- 
тивно включване с позитивна психологична подкрепа;

- Училище: съвместни с родителите програми за възпитание, обучение за хранене и двигателна активност в училище;

- Групи връстници: за повишаване познанията и психоемоционална подкрепа.

Много експерти са загрижени за бъдещето, предвид здравето на децата днес. Това прави епидемията от затлъстяване с риска от развитие на ХБЗ, диабет, сърдечно-съдови усложнения, рак и др. сериозно предизвикателство пред лекари, семейство, общество. Налага се обсъждане на следните приоритети:

- Работа с родители и настойници;

- Осигуряване на здравословна храна в училищата;

- Подобряване достъпа до здравословни храни на достъпни цени;

- Увеличаване на физическата активност. В борбата с наднорменото тегло е нужна мотивация. Тя осигурява постоянен контрол на теглото и успешно лечение.

Практически съвети към педиатри и общопрактикуващи лекари:

- Подробна анамнеза на деца със затлъстяване.

- Да се изключат органични нарушения.

- Да се определи наличието на бъдещи заболявания.

- Да се прецени рискът за бъдещо развитие на съпътстващи заболявания.

- Голям брой деца страдат от болести, свързани със затлъстяването.

- Да се търсят генетични причини за затлъстяването.

- Да се търсят фактори на средата като заседнал начин на живот и увеличена консумация на високо калорийни храни.

При децата, които нямат изявени медицински проблеми, идентифицирането на рисковите фактори е от съществено значение за намаляване риска от развитие на метаболитни усложнения.

Лечението е най-успешно, когато подходът е насочен към родителите със съвети за промяна в начина на живот на семейството.

При тези деца ключов елемент играе семейството, т.е. балансирано здравословно хранене и увеличената физическа активност в семейната среда. Целите на правилното хра- нене в детска възраст са: да се постигне нормално телесно тегло и да се развият здравословни хранителни навици, които да се поддържат през целия живот на детето.

\section{ЛИТЕРАТУРА}

1. Станимирова Н., Л. Пенева, Ц. Балтова. Физическо пубертетно развитие на българските деца. Норми и стандартни криви, 2007.

2. Трифонова Л., Хранене на децата от 1 до 16 години, София, 2010.

3. Beddhu S., et. al., Associations of metabolic syndrome with inflammation in CKD: results From the Third Netional Health And Nutrition Examination Survey, Am. J. Kidney Dis., 2005, 46, 577- 586.

4. Ding W., W. Cheung, Mak. R, Impact of obesity on kidney function and blood pressure in children, World J. Nephrol., 2015, 4 (2), 223- 229.

5. Ding W., Mak R., Early marcers of obesity- related renal injury in childhood., Pediatr. Nephrol., 2015, 3-, 1-4.

6. Galcheva S., V. Yotova, Y. Yotov, K. Grozdeva, V. Stavrev, V. Tzaneva, Waist circumference persentile curves for Burgarian children and adolescens aged 6- 18 years

7. Gunta S., Mak R., Is obesity a risk factor for chronic kidney disease? Pediatr. Nephrol., 2013, 28, 1949- 1956.

8. Hall J., The kidney, hypertension and obesity, Hypertension, 2003, 41, 625- 633.

9. Hsu C et. al., Body mass index and risk for endstage renal disease, Ann. Intern, Med., 2006, 144, 21-28.

10. Filler G., Reimao S., et. al., Pediatric nephrology patients are overweight: 20 years experience in a single Canadian tertiary pediatric nephrology clinic, Int. Urol. Nephrol. 2007, 39, 1235-1240.

11. Pantoja Zuzuarregui J., et. al., The effect obesity on kidney length in a healthy pediatric population, Pediatr. Nephrol., 2009, 24, 2023- 2027.

12. Ramkumar N. et. al., Association of obesity with inflammation in chronic kidney disease: a cross sectional study, J. Ren Nutr., 2004, 14, 201-207.

13. Sarafidis P., Ruilope L., Insuline resistence, hyperinsulinemia and renal injury: mechanisms and implications, Am.J. Nephrol.2006, 26, 232-244.

14. Wang $Y$, Chen $X$, Song $Y$, et. al., Association between obesity and kidney disease $\& d$ systematic review and meta- analysis, Kidney Int., 2008, 73, 19-33.

15. Wu Y., Liu Z., Zeng C., Obesity related glomerulopathy: insights from gene expression profiles of the glomeruli derived from renal biopsy samples. Endocrinology, 2006, 147, 44-50. 